\title{
PERAN MASYARAKAT PESERTA PEMILIHAN UMUM 2019 DALAM MENANGGULANGI POLITIK UANG DI DESA PULOSARI KECAMATAN KEBAKKRAMAT KABUPATEN KARANGANYAR
}

\author{
Oleh: \\ Didik Surawan, ${ }^{1)}$ Yusuf ${ }^{2)}$ \\ 1) Mahasiswa PPKn \\ 2) Dosen Prodi PPKn FKIP UNISRI
}

\begin{abstract}
ABSTRAK
Tujuan penelitian ini adalah untuk: 1) Mengetahui peran masyarakat dalam menanggulangi politik uang dalam pelaksanaan pemiliham umum 2019 di Desa Pulosari Kecamatan Kebakkramat Kabupaten Karanganyar. 2) Mengetahui faktor-faktor yang melatar belakangi masyarakat menerima politik uang dalam pelaksanaan pemiliham umum 2019 di Desa Pulosari Kecamatan Kebakkramat Kabupaten Karanganyar. 3) Untuk mengetahui upaya yang dilakukan oleh masyarakat dalam memanggulangi politik uang pada pemilu 2019.

Metode penelitian menggunakan pendekatan deskriptif kualitatif, sumber data menggunakan data primer dan data sekunder. Subjek penelitian ini adalah masyarakat peserta pemilu 2019 di Desa Pulosari Keacamatan Kebakkramat Kabupaten Karanganyar. Teknik pengumpulan data menggunakan wawancara, observasi dan dokumentasi. Keabsahan data menggunakan triangulasi sumber dan triangulasi metode. Teknik analisis data menggunakan model analisis interaktif.

Berdasarkan hasil penelitian diperoleh kesimpulan bahwa: 1) Peran masyarakat dalam menanggulangi politik uang dalam pelaksanaan pemiliham umum 2019 di Desa Pulosari Kecamatan Kebakkramat Kabupaten Karanganyar masih rendah, masyarakat Desa Pulosari cenderung membiarkan dan bersikap terbuka terhadap praktik politik uang yang terjadi di desanya dan tidak melaporkan praktik politik uang tersebut kepada pihak pengawas pemilu. 2) Faktor-faktor yang melatarbelakangi masyarakat Pulosari dalam melakukan Money politics dalam pemilu yaitu karena masalah ekonomi, kebiasaan ketika pemilu, pendidikan politik yang rendah, sehingga masyarakat cenderung terbuka dan menerima kegiatan money politics yang dilakukan oleh calon kandidat dan menerima segala macam bentuk pemberian. Pemberian uang yang membuat masyarakat merasa wajib untuk mengikuti proses pemilu karena adanya bentuk kesepakatan tidak tertulis dengan unsur-unsur paksaan dari para pelaku money politics. 3) Upaya yang dapat dilakukan menanggulangi politik uang dalam pelaksanaan pemiliham umum 2019 di Desa Pulosari Kecamatan Kebakkramat Kabupaten Karanganyar yaitu dilakukan dengan memberikan pendidikan politik kepada masyarakat serta melaporkan kejadian politik uang kepada pengawas pemilu yang disertai dengan bukti-bukti yang cukup.
\end{abstract}

Kata Kunci: Peran Masyarakat, Pemilihan Umum, Politik Uang 


\begin{abstract}
The aims of this Research ari 1) to find laut The role of Community in talking Money politics in The 2019 general Election in Pulosari, Kebakkramat, Karanganyar. 2) to Find out The factors underlying The Community to accept Money politics in The implementation of the 2019 general election in Pulosari, Kebakkramat, Karanganyar. 3) to Finn out The efforts made by the community in tackling Money politics in the 2019 general Election.The Research method Led a descriptive qualitatieve approach. Data source used primary data and secondary data. The research subject bas the community participating in the 2019 general election in Pulosari, Kebakkramat, Karanganyar. The technique of data collecting used interview, observation, and documentation. Data validity used riangulation of source and triangulation of method. The technique of data analysis used interative analysis model. Based on the research result, it could concluded that 1) the role of the community in tackling money politics in the implementation of the 2019 general election in Pulosari, Kebakkramat, Karanganyar was still low. The community of Pulosari tended do allow and be open to the practice of money politis to the election supervisors. 2) the factors underling the community to accept money politics in the general election were caused by economic problems, habits during general election, low political education os that the people felt obliged to take part in the electoral process because of the for of of unwritten agreeements with elements of coercion from the pertrerators of money politics. 3) the efforts made by the community in tackling money politics in the implementation of the 2019 general election in Pulosari, Kebakkramat, Karanganyar was carried out by providing political education to the community and reporting the incidence of money politics to the supervisor of the general election accompanied by sufficient evidence.
\end{abstract}

Keywords: The Role of The Community, General Election, Money Politics.

\section{PENDAHULUAN}

Demokrasi sebagai dasar hidup bernegara memberi pengertian bahwa pada tingkat terakhir rakyat memberikan ketentuan dalam masalah pokok mengenai kehidupannya, termasuk dalam menilai kebijakan negara, karena ketentuan tersebut menentukan kehidupan rakyat (Moh. Mahfud MD, 1999: 8). Negara Indonesia adalah negara demokrasi yang berasas pancasila. Pemilihan Umum (Pemilu) dianggap lambang, sekaligus tolak ukur, dari demokrasi itu (Miriam Budiardjo, 2010: 461). Indonesia merupakan salah satu negara yang menganut paham demokrasi. Di kebanyakan negara demokrasi, pemilihan umum dianggap sebagai lambang, sekaligus tolak ukur dari sebuah demokrasi. Pemilihan Umum adalah sesuatu dimana milih seseorang untuk mengisi jabatan politik tertentu. Pemilu merupakan sesuatu negara yang demokrasi dan berkedaulatan rakyat telah menjunjung tinggi nilai-nilai kebenaran dan hak-hak rakyatnya. Pemilihan Umum ialah pesta demokrasi yang dilaksanakan secara langsung, umum, bebas, rahasia, jujur dan adil dalam Negara Kesatuan Republik Indonesia berlandaskan Pancasila dan UUD RI 1945.

Dalam pelaksanannya, pemilihan umum (pemilu) di Indonesia sering terlihat tidak sehat. Pemilihan umum yang dinilai sebagai pesta demokrasi pun ternyata belum bisa mengimplementasikan sistem demokrasi yang sesungguhnya. Didalam proses 
pelaksanaannya, pemilihan umum (pemilu) masih di suguhi kecurangan yang dilakukan oleh kandidat pemilu maupun partainya sendiri. Salah satu kecurangan pemilu adalah politik uang yang memaksa masyarakat untuk memilih peserta pemilihan umum (pemilu) yang melakukan politik uang tersebut.

Pemilihan umum berfungsi sebagai alat penyaring bagi negarawannegarawan yang akan mewakili dan membawa suara rakyat di dalam lembaga dewan perwakilan rakyat, mereka yang terpilih dianggap sebagai orang atau kelompok yang mempunyai kemampuan atau kewajiban untuk bicara dan bertindak atas nama suatu kelompok yang lebih besar melalui partai politik. Pemilihan Umum (Pemilu) di Indonesia pada awalnya ditujukan untuk memilih anggota lembaga perwakilan, yaitu DPR, DPRD, dan DPD. Setelah amandemen ke-IV UUD 1945 pada 2002, pemilihan Presiden dan Wapres (Pilpres), yang semula dilakukan oleh MPR, disepakati untuk dilakukan langsung oleh rakyat sehingga pemilihan Presiden (Pilpres) pun dimasukan ke dalam agenda pemilu. Pemilihan Presiden (Pilpres) sebagai bagian dari pemilihan umum diadakan pertama kali pada pemilu 2004. Pemilu 2019 adalah pemilihan legislatif dengan Pilpres yang diadakan secara bersamasama. Hal ini dilakukan berdasarkan Putusan Mahkamah Konstitusi Nomor 14 / PUU-11/2013 tentang pemilu serentak, yang bertujuan untuk meminimalkan pembiayaan negara dalam pelaksanaan pemilu, meminimalisir politik biaya tinggi bagi peserta pemilu, serta politik uang yang melibatkan pemilih, penyalahgunaan kekuasaan atau mencegah politisasi birokrasi, dan merampingkan skema kerja pemerintah.

Tepat pada tanggal 17 April 2019 dilaksanakan pemilihan Umum Legislatif dan pemilihan Presiden yang serentak diikuti oleh seluruh Kota/Kabupaten dan seluruh Provinsi se-Indonesia, termasuk juga Desa Pulosari Kecamatan Kebakkramat Kabupaten Karanganyar. Pemilihan Umum tersebut bertujuan untuk pemilihan Anggota Legislatif dan Presiden Indonesia yang baru yang akan menjabat pada periode 2019-2024 untuk menggantikan Presiden terpilih sebelumnya. Pemilihan Presiden Indonesia Periode 2019-2024 kali ini diikuti oleh dua calon Presiden dan calon wakil Presiden. Dua kandidat itu adalah kandidat dengan nomor urut 1 (satu) adalah Joko Widodo-Ma'ruf Amin dan Prabowo Subianto-Sandiaga Uno sebagai kandidat dengan nomor urut dua. Kedua calon Presiden yang telah diusung oleh masing-masing partai pendukungnya tentu memiliki basis massa pendukung yang tidak sedikit dan terdapat persaingan elektabilitas sehingga masingmasing calon berusaha untuk mendapatkan suara dengan melakukan berbagai macam cara sekalipun, termasuk pelanggaran dalam Pemilu.

Sulit disangkal bahwa transisi menuju demokratisasi di Indonesia dapat terhambat oleh yang mungkin pada awalnya kurang diperhitungkan, seperti politik uang. Pada akhirnya mereka yang punya uang saja yang akan memegang kedaulatan dan mengontrol kekuasaan, jargon-jargon kedaulatan rakyat akan tereliminasi pada tataran praksis (Indra Ismawan, 2009: 69). Menurut kacamata Pengamat Politik, pemilihan Presiden (Pilpres) 2019 berada dibawah bayangbayang ancaman politik uang. Kekhawatiran itu muncul melihat tren penggunaan politik uang memerlukan kapasitas finansial yang cukup besar karena menjangkau pemilih dengan ruang lingkup luas berskala Indonesia. Oleh karena itu, politik uang di pemilihan Presiden (Pilpres) hanya bisa dilakukan oleh kekuatan politik berdana besar yang disokong oleh pendana besar. Sehingga 
dalam proses pelaksanaan pemilihan umum (Pemilu) tak dapat dilepaskan dari berbagi persoalan politik yang muncul dan kerap kali terjadi di masyarakat. Salah satu fenomena politik yang mendapat perhatian dari berbagai kalangan saat ini adalah maraknya praktik politik uang di Indonesia.

Uang merupakan faktor darurat yang berguna untuk meraih suara sebanyak-banyaknya untuk seorang caleg, sekaligus untuk mengendalikan wacana strategis terkait dengan sebuah kepentingan politik dan kekuasaan. Karena pada dasarnya, politik adalah seni. Dimana seseorang bebas mempengaruhi dan memaksakan kepentingan pribadi dan kelompoknya pada pihak lain melalui berbagai sarana, termasuk uang. Politik uang dalam Bahasa Indonesia adalah memberi/membeli, arti memberi/membeli dalam buku kamus besar Bahasa Indonesia adalah uang sogok. Komisi Pemilihan Umum menganggap politik uang bukan lagi sekedar penyimpangan. Politik uang adalah pelanggaran dalam pemilu.

Adanya praktik politik uang yang dilakukan caleg untuk mendulang suara pada tiap pemilu banyak terjadi di Indonesia, salah satu terjadi di Desa Pulosari Kecamatan Kebakkramat Kabupaten Karanganyar. Menurut laporan masyarakat, ditemukan aksi praktek politik uang dalam pemilu yang dilakukan oleh partai politik, para caleg maupun tim sukses masing-masing kandidat kepada masyarakat secara umum.

Money Politic bukan lagi menjadi rahasia umum, karena itu sangat menentukan tinggi rendahnya angka prosentase pemilih pada saat pemilihan umum (pemilu). Berbicara tentang money politic, dimana yang sudah disinggung di atas bahwasanya money politic sudah tidak tabu untuk diperbincangkan di khalayak umum ataupun kalangan masyarakat. Daftar Pemilih Tetap (DPT) pada Pemilu 2019 di Desa Pulosari Kecamatan Kebakkramat Kabupaten Karanganyar saat ini cukup banyak, berdasarkan data yang diperoleh dari Kantor Kepala Desa Pulosari diperoleh jumlah DPT Pemilu 2019 yaitu sebanyak 4.080 pemilih yang terbagi dalam 20 Tempat Pemungutan Suara (TPS).

Alasan pemilihan judul dalam penelitian ini karena praktik politik uang telahmenjadi tradisi turun-temurun, mulai dari tingkat atas hingga bawah, oleh dari itu harus disikapi dengan serius. Persoalan yang terkesan remeh namun memiliki implikasi negatif yang sangat besar bagi perkembangan demokrasi dan penegakkan hukum di Indonesia. Money politics membuat proses politik menjadi bias. Akibat penyalahgunaan uang, pemilu sulit menampakkan ciri kejujuran, keadilan serta persaingan yang sehat. Pemilu yang demikian akhirnya akan membentuk pemerintahan yang kotor dan tidak bertanggujawab. Alasan kedua dalam penelitian ini yaitu rendahnya pemahaman masyarakat mengenai dampak dari praktik politik uang dalam pelaksanaan pemilu 2019.

Tujuan penelitian ini adalah untuk: 1) Mengetahui peran masyarakat dalam menanggulangi politik uang dalam pelaksanaan pemiliham umum 2019 di Desa Pulosari Kecamatan Kebakkramat Kabupaten Karanganyar. 2) Mengetahui faktor-faktor yang melatar belakangi masyarakat menerima politik uang dalam pelaksanaan pemiliham umum 2019 di Desa Pulosari Kecamatan Kebakkramat Kabupaten Karanganyar. 3) Untuk mengetahui upaya yang dilakukan oleh masyarakat dalam memanggulangi politik uang pada pemilu 2019.

\section{METODE PENELITIAN}

Metode penelitian menggunakan pendekatan deskriptif kualitatif, sumber data menggunakan data primer dan data 
sekunder. Subjek penelitian ini adalah masyarakat peserta pemilu 2019 di Desa Pulosari Keacamatan Kebakkramat Kabupaten Karanganyar. Teknik pengumpulan data menggunakan wawancara, observasi dan dokumentasi. Keabsahan data menggunakan triangulasi sumber dan triangulasi metode. Teknik analisis data menggunakan model analisis interaktif.

\section{HASIL PENELITIAN DAN PEMBAHASAN}

1. Peran Masyarakat

dalam Menanggulangi Politik Uang Dalam Pelaksanaan Pemiliham Umum 2019 di Desa Pulosari Kecamatan Kebakkramat Kabupaten Karanganyar

Pelaksanaan Pemilu 2019 di Desa

Pulosari Kecamatan Kebakkramat Kabupaten Karanganyar diikuti oleh 4.080 pemilih yang terbagi dalam 20 Tempat Pemungutan Suara (TPS). Berikut peneliti sampaikan karakteristik pemilih peserta pemilu 2019 di Desa Pulosari Kecamatan Kebakkramat Kabupaten Karanganyar ditinjau dari agama, jenis kelamin, umur dan pemilih pemula.

Selanjutnya sebelum membahas mengenai peran masyarakat dalam menanggulangi politik uang dalam pelaksanaan Pemiliham Umum 2019 di Desa Pulosari Kecamatan Kebakkramat Kabupaten Karanganyar, peneliti melakukan wawancara kepada responden mengenai pemahaman tentang pelaksanaan pemilu 2019 yaitu sebagai berikut:

a. Pemahaman Masyarakat mengenai

Pelaksanaan Pemilu 2019

Hasil wawancara dengan masyarakat Desa Pulosari mengenai pemahaman masyarakat mengenai pemilu 2019 menunjukkan bahwa dari 10 responden menyatakan sangat memahami sebanyak 2 orang (20\%), memahami sebanyak 6 orang (60\%), kurang memahami sebanyak 1 orang $(10 \%)$ dan responden yang menjawab tidak memahami tidak ada. Hasil wawancara dengan Bapak Sutrisna selaku Tokoh Masyarakat Desa Pulosari yang berprofesi sebagai pedagang mengatakan bahwa:

Mengenai pemilu 2019 menurut saya adalah penyelenggaraan pemilu untuk memilih presiden dan wakil presiden, DPR RI, DPRD Provinsi, DPRD Kabupaten/Kota serta memilih anggota DPD (Hasil Wawancara Tanggal 19 Februari 2019).

Pendapat tersebut di atas didukung dengan hasil wawancara dengan Bapak Bambang Iswanto selaku Ketua Karang Taruna Desa Pulosari yang berprofesi sebagai peagang menyatakan bahwa:

Menurut saya pemilihan umum 2019 berbeda dengan pemilihan umum pada tahun 2014, dalam pemilihan umum tahun 2019 pemilihan presiden dan wakil presiden dilaksanakan secara bersamaan dengan pemilihan calon anggota legislatif dan anggota DPD (Hasil Wawancara Tanggal 20 Februari 2019).

Pendapat yang sama disampaikan oleh Bapak Sutino selaku Kepala Desa yang berprofesi sebagai wiraswasta mengungkapkan bahwa:

Dalam pelaksanaan pemilu 2019 ini masyarakat secara umum sudah memahami, sebab KPU sebegai penyelenggara pemilu 2019 sudah melakukan sosialisasi, baik melalui media televisi, media cetak maupun media online. Sehingga dengan adanya sosialisasi tersebut masyarakat sudah memahami mengenai pelaksanaan pemilu 2019 yaitu memilih presiden dan wakil presiden, calon legislatif, dan 
anggota DPD (Hasil Wawancara

Tanggal 21 Februari 2019).

Pernyataan kemudian diutarakan oleh beberapa informan, salah satu dari mereka, Bapak Budi Pratama yang berprofesi sebagai buruh berpendapat:

Pemilu 2019 ini adalah memilih calon presiden dan anggota DPR serta DPD, olah karena itu sebagai pemilih, saya memilih karena ingin menggunakan hak pilih sebagai warga Negara Indonesia. Dan alasan saya memilih calon presiden yang akan saya pilih karena kandidat yang saya pilih adalah pemimpin yang jujur, bersih, dan merakyat (Hasil Wawancara Tanggal 21 Februari 2019).

Berdasarkan pernyataan di atas menunjukkan bahwa responden memahami mengenai pelaksanaan pemilu 2019, hal ini tidak berbeda dengan penjelasan responden lainnya yaitu Bapak Purnomo selaku Tokoh Masyarakat yang berprofesi sebagai Petani menyatakan :

Sebagai masyarakat Indonesia yang mengakui pentingnya demokrasi adalah sebuah keharusan dalam menetapkan pilihan pada pilpres 2019 dan ingin supaya Indonesia lebih maju dan makmur dalam segala aspek, terutama pendidikan dan kesehatan. Oleh karena itu dalam pemilu 2019 saya dalam memilih calon presiden maupun calon anggota DPR harus yang memiliki visi dan misi untuk menyejahterakan masyarakat (Hasil Wawancara Tanggal 21 Februari 2019).

Hasil Wawancara
Bapak Samidi selaku
Masyarakat Desa Polosari yang
berprofesi sebagai Peternak
menyatakan bahwa:
Pemilu 2019 menurut saya adalah
memiluh calon anggota DPR, anggota
DPD serta memilih calon presiden

dan calon wakil presiden untuk periode lima tahun mendatang (Hasil Wawancara Tanggal 21 Februari 2019).

Menurut peneliti dari pernyataan informan di atas, masyarakat sudah memahami pelaksanaan pemilihan 2019, masyarakat lebih mengharapkan kemajuan bangsa dengan menetapkan pilihan pada kandidat yang mempunyai kinerja yang baik. Perilaku pemilih tersebut merupakan hasil dari proses sosialisasi, dengan akses informasi ide dan visi misi serta program yang diusung kandidat. Masyarakat Desa Pulosari pada dasarnya sudah memahami bahwa pelaksanaan Pemilu 2019 tersebut dilaksanakan pada tanggal 17 April 2019 yang akan memilih para anggota dewan legislatif DPR RI, DPD RI dan DPRD serta akan memilih presiden dan wakil presiden.

b. Pemahaman Masyarakat terhadap

\section{Caleg Peserta Pemilu 2019}

Masyarakat Desa Pulosari dalam pelaksanaan pemilu 2019 ini mengenal caleg berdasarkan unsur kekrabatan dan kontribusi caleg terhadap masyarakat. Oleh karena itu banyak caleg yang menggunakan segala cara seperti money politic, mobilisasi massa, dan lain-lain untuk bisa memenangkan pemilihan umum, pertanyaan ini sependapat dengan pandangan Bapak Sutrisna selaku Tokoh Masyarakat Desa Pulosari menyatakan bahwa:

Masyarakat memahai caleg, ketika caleg tersebut melakukan sosialiasi di Desa Pulosari. Seorang caleg yang menggunakan segala cara untuk memperoleh kekuasaan, seperti menggunakan money politic (politik uang), maka hasilnya adalah saat caleg tersebut menjadi anggota legislatif juga akan menggunakan segala cara untuk mengembalikan uang yang sudah dikeluarkan tersebut. Sehingga 
kemudian orientasi dari caleg tersebut bukan untuk kepentingan rakyat, melainkan untuk kepentingan pribadinya sendiri (Hasil Wawancara Tanggal 19 Februari 2019).

Dalam pileg yang dilakukan masyarakat memilih caleg karena latar belakang partai politik yang mengusungnya atau karna faktor lain seperti keuntungan yang didapat, hal itu sependapat dengan apa yang diungkapkan oleh Bapak Bambang Iswanto selaku Ketua Karang Taruna Desa Pulosari yang menyatakan bahwa:

Menurut saya pilihan masyarakat saat ini kebanyakan masyarakat akan memilih para caleg yang mereka kenal dalam artian kedekatan pernah bertemu atau pernah memberikan sesuatu. Banyaknya para caleg saat ini membuat masyarakat menjadi bingung untuk menentukan pilihannya, jadi mereka akan bersikap pragmatis dengan memberikan suara mereka pada para caleg yang memberikan mereka keuntungan (Hasil Wawancara Tanggal 20 Februari 2019)

Selanjutnya menurut Bapak Sutino selaku Kepala Desa mengungkapkan bahwa:

Kembali kepada kedekatan dan kontribusi yang diberikan caleg tersebut pada masyarakat. Seorang caleg biasanya akan dikenali oleh masyarakat jika sudah mengenal lama seorang caleg tersebut, serta kontribusi apa yang diberikan oleh caleg kepada masyarakat. Jika caleg tersebut memberikan kontribusi kepada masyarakat maka masyarakat akan memilihynya dalam pemilu nanti (Hasil Wawancara Tanggal 21 Februari 2019). jika berbicara tentang tindakan yang dilakukan oleh caleg hanyalah merupakan politik pencitraan, pendapat sama juga diutarakan oleh Bapak Budi Pratamabahwa:

Tindakan yang dilakukan oleh caleg yang selama ini kita lihat hanyalah merupakan bentuk strategi yang digunakan untuk mendapatkan empati dari masyarakat, hal itu dilakukan dengan melakukan pencitraan melalui tindakan yang dilakukan seperti membagikan bantuan, dll kepada masyarakat (Hasil Wawancara Tanggal 21 Februari 2019).

Hasil wawancara dengan Bapak Purnomo berpendapat mengenai sikap memilih masyarakat yang dipengaruhi oleh persepsinya pada caleg, menurut beliau:

Persepsi yang dimiliki oleh caleg sangat mempengaruhi perilaku memilih masyarakatnya, karena menurut saya persepsi itu dibangun oleh masyarakat berdasarkan apa yang mereka rasakan dan mereka dapatkan dari seorang caleg tersebut selama ini (Hasil Wawancara Tanggal 21 Februari 2019).

Perilaku memilih yang ditunjukkan oleh masyarakat Pulosari merupakan bentuk persepsi mereka pada caleg maupun parpol yang mengusungnya, dikemukan oleh Bapak Samidi yang mengatakan bahwa:

Pandangan masyarakat pada seorang caleg atau parpol mempengaruhi perilaku memilih masyarakat karena beberapa faktor seperti salah satunya kontribusi yang diberikan oleh caleg atau parpol terhadap masyarakat di lingkungan dapilnya. Misalnya seorang caleg atau parpol yang memberikan bantuan bahan bangunan untuk pembangunan jalan 
desa. seperti yang terjadi dikabupaten tarik, seorang bupati memberikan kambing sebagai motivasi agar masyarakat tidak lagi melakukan golput (Hasil Wawancara Tanggal 21 Februari 2019).

c. Pemahaman Masyarakat Manfaat

Pelaksanaan Pemilu 2019

Berdasarkan hasil wawancara dengan para responden masyarakat Desa Pulosari diperoleh informasi mengenai manfaat pelaksanaan pemilu 2019. Hasil wawancara dengan Bapak Sutrisna selaku Tokoh Masyarakat Desa Pulosari menyatakan bahwa:

Melalui pelaksanaan pemilu 2019 ini memiliki manfaat dalam pembangunan negara Indonesia untuk 5 tahun mendatang, oleh karena itu kita sebagai warga negara harus menggunakan hak suara kita dalam menentukan pemimpin yang mampu memajukan negara Indoensia, baik dari segi ekonomi dan pembangunan (Hasil Wawancara Tanggal 21 Februari 2019).

Pendapat yang sama disampaikan oleh Bapak Bambang Iswanto selaku Ketua Karang Taruna Desa Pulosari yang menyatakan bahwa:

Pelaksanaan pemilu 2019 ini memiliki manfaat bagi kemajuan bangsa Indonesia, terutama dalam pemilihan calon presiden. Dalam menetapkan pilihan kepada seorang kandidat presiden, pertama-tama, saya melihat dari latar belakang kandidat dan track recordnya, kedua, apa yang menjadi landasan kandidat tersebut untuk menjadi presiden 2019 dilihat dari visi dan misinya, setelah menganalisa itu semua ternyata tidak ada pilihan lain yang lebih baik dari yang saya dukung (Hasil Wawancara Tanggal 21 Februari 2019).
Berdasarkan hasil wawancara dengan para responden di atas dapat peneliti jelaskan bahwa semua responden sudah memahami pentingnya pelaksanaan pemilu 2019 serta manfaat daru pelaksanaan pemilu, yaitu memilih pemimpin terutama presiden Indoensia untuk 5 tahun mendatang.

\section{d. Politik Uang dalam Pelaksanaan Pemilu 2019 di Desa Pulosari}

Keberadaan calon anggota legislatif yang curang dalam pemilihan umum dengan memberikan uang atau hadiah dalam kegiatan kampanye memang masih sulit untuk dihindari, hal ini terlihat bahwa masih ada masyarakat yang mendapatkan uang dari caleg atau tim suksesnya dalam kegiatan pemilu, namun meskipun seperti itu mayoritas masyarakat di Desa Pulosari menyatakan bahwa kegiatan pembagian uang dari caleg atau tim suksesnya tidak ada. Adanya sebagian kecil masyarakat di Desa Pulosari yang masih menerima uang dari caleg atau tim suksesnya dalam kegiatan pemilu ini sangat mungkin disebabkan oleh faktor ekonomi yang senantiasa menjerat masyarakat, sehingga dengan keadan tersebut tidak ada pilihan lain yang bisa dilakukan kecuali menerima uang atau hadiah yang diberikan oleh calon legislatif atau tim suksesnya pada saat kampanye. Berdasarkan hasil wawancara dengan Bapak Sutrisna selaku Tokoh Masyarakat Desa Pulosari menyatakan bahwa: Politik uang umumnya dilakukan simpatisan, kader atau bahkan pengurus partai politik menjelang hari $\mathrm{H}$ pemilihan umum. Praktik politik uang dilakukan dengan cara memberi uang kepada masyarakat dengan tujuan agar mereka memberikan suaranya untuk caleg yang bersangkutan (Hasil Wawancara Tanggal 19 Februari 2019). 
Hal yang sama disampaikan oleh Bapak Bambang Iswanto selaku Ketua Karang Taruna Desa Pulosari yang menyatakan bahwa:

Money politics itu sebenarnya adalah upaya membeli suara dengan berupa barang, uang ataupun jasa. Politik aung dalam pemilu menunjukkan betapa lemahnya pengawasan bawaslu yang sebenarnya memiliki tugas dalam mengawasi dan mencegah politik uang. Sehingga hasil yang didapatkan jujur, adil, dan sejahtera. Tidak jarang kita melihat kinerja perilaku para wakil rakyat yang dipilih dalam pemilu banyak memberitakan penyimpangan dan pelanggaran hukum yang dilakukan oleh para wakil rakyat. Dan banyak pula anggota DPRD yang bermasalah dalam kasus hukum seperti kasus korupsi, kode etik, ketidak hadiran dalam rapat penting. Dalam pemilu legislatif saat ini, money politics ibarat sesuatu yang tidak dapat dibuktikan tetapi ada di tengah kehidupan masyarakat. Dalam pemilu legislatif maupun pemilu presiden, money politics ibarat kentut, dapat dicium baunya namun tidak dapat dilihat wujudnya (Hasil Wawancara Tanggal 20 Februari 2019).

Hasil wawancara dengan Bapak Sutino selaku Kepala Desa mengungkapkan bahwa:

Praktik politik uang ini dilakukan secara terang-terangan lewat sumbangan baik sarana maupun prasarana ataupun renovasi sarana sosial bahkan individu-individu menerima pemberian uang panas ini, dengan syarat memberikan suaranya pada ajang pemungutan suara. Ini sudah menjadi rahasia umum bahwa para calon legislatif mengeluarkan uang yang banyak untuk mendapatkan kursi di DPRD (Hasil Wawancara Tanggal 21 Februari 2019).

\section{Faktor yang Mempengaruhi Masyarakat Desa Pulosari Menerima Money Politics \\ Kegiatan Money Politics pada} pemilu kini sudah menjadi fenomena yang sering terjadi dimana Money Politics menjadi tolak ukur dari seorang kandidat dalam meraih simpati dari msyarakat guna memenagkan pemilu, namun tidak semua juga kandidat menmpuh jalur Money politics dalam memenagkan pemilu walaupu dalam hal tersebut kemungkinannya sangat kecil, hal tersebut sebabkan karena politik yang dipahami saat ini oleh masyarakat Pulosari yang minim terhadap pengetahuan dan arti dari politik itu sendiri justru hanya mengartikan pemilu sebagai sesuatu hal yang mendatangkan keuntungkan bagi pemilih dan yang dipilih bukan memandang pemilu sebagai jalur yang digunakan dalam mengerakkan Indonesia kearah yang lebih baik. Pendidikan dan kebiasaan masyarakat ketika menjadi pemilih maupun yang dipilih justru saling menyempitkan pemikiran akan arti dari pemilu yang dimana kandidat hanya mengfokuskan mengejar kekuasaan dari proses pemilu sedangkan pemilih yang hanya menanti pemberian uang sebagai alat intervensi terhadap partisipasinya dalam pemilu. Hasil wawancara mengenai faktor yang melatarbelakangi masyarakat desa pulosari menerima money politics dapat disajikan dalam tabel berikut:

Tabel 13. Pemahaman Masyarakat Mengenai Faktor yang Melatarbelakangi Masyarakat Desa Pulosari Menerima Money Politics

\begin{tabular}{clcc}
\hline No. & Jawaban Responden & $\begin{array}{c}\text { Jumlah } \\
\text { Responden }\end{array}$ & Persentase \\
\hline 1. & $\begin{array}{l}\text { Kebiasaan dalam } \\
\text { pemilu }\end{array}$ & 3 & $30 \%$ \\
\hline 2. & Pengaruh Ekonomi & 2 & $20 \%$ \\
\hline 3. & Pendidikan Poltik yang & 5 & $50 \%$ \\
\hline
\end{tabular}




\begin{tabular}{ccc}
\hline Rendah & & \\
\hline Jumlah & 10 & $100 \%$ \\
\hline
\end{tabular}

Sumber Data: Hasil Wawancara

Keadaan

tersebut

mengakibatkantombulnya politik uang. Masyarakat yang acuh terhadap pemilu dengan mudah menerima pemberian dari para peserta pemilu dan jika tidak mendapatkan pemberian uang maupun barang dari calon kandidat lebih cenderung tidak ikut dalam partisipasi (Golput). Masyarakat yang berada pada strata ekonomi lemah lebih cenderung juga memiliki pendidikan politik yang minim dan hal tersebut makin memperparah arti dari demokrasi karena mereka merasa segala sesuatu itu penting untuk dikerjakan apabila menghasilkan dan begitupun sebaliknya jika tidak menghasilkan maka tidaklah penting bagi mereka skalipun hal tersebut adalah pemiliu, maka mereka lebih baik tidak berpartisipasi (Golput).

\section{Upaya Menanggulangi Politik Uang dalam Pemilu 2019}

Hasil penelitian mengenai upaya menanggulangi politik uang dalam pemilu 2019 menurut Bapak Sutrisna selaku Tokoh Masyarakat Desa Pulosari yang berprofesi sebagai pedagang mengatakan bahwa:

Perlu adanya pembelajaran politik. Jadi pembelajaran politik bukan hanya menjadi tanggung jawab KPU semata, tapi pembelajaran politik ini juga berlaku bagi lembaga politik itu sendiri untuk memberikan pemahaman mengenai pemilu yang bersih kepada masyarakat (Hasil Wawancara Tanggal 19 Februari 2019).

Pendapat tersebut di atas didukung dengan hasil wawancara dengan Bapak Bambang Iswanto selaku Ketua Karang Taruna Desa Pulosari yang berprofesi sebagai peagang menyatakan bahwa:
Perlu adanya pendidikan politik kepada masyarakat, sehingga masyarakat dalam menentukan pilihannya bukan karena emosi, tetapi berdasarkan pertimbangan rasio atau bagaimana menyalurkan pilihannya dengan pikiran, nalar mereka, intelektual mereka, pendidikan politik, pencerahan politik. Sehingga boleh dikatakan jangan memilih kucing dalam karung, itu artinya kita memilih tidak melihat dari kualitas orang tersebut. Tapi orang tersebut harus menunjukan kualitas, kemampuan sehingga masyarakat memilih dengan kecerdasan mereka. (Hasil Wawancara Tanggal 20 Februari 2019).

Pendapat yang sama disampaikan oleh Bapak Sutino selaku Kepala Desa yang berprofesi sebagai wiraswasta mengungkapkan bahwa:

Perlu adanya pendidikan politik dengan membangun kecerdasan politik dalam masyarakat, harus dibangun bersama, antara KPU, Panwaslu, Partai Politik sendiri yang memiliki kader-kader politik tersebut. Sehingga menurut penulis kepada partai politik yang memiliki kader tersebut juga memberikan support bagaimana membangun kecerdasan dalam masyarakat, sehingga jika ada kader yang melakukan hal - hal tersebut partai politik bisa melakukan penekanan, baik apakah dia dikeluarkan sebagai calon atau penekananpenekanan lain. Sehingga yang dijual bukan uang, namun kualitas, visi dan misi daripada kader tersebut, untuk menjadi perhatian bersama dari semua stake holder dalam kehidupan bermasyarakat, berpolitik, berdemokrasi. (Hasil Wawancara Tanggal 21 Februari 2019). 
Sesuai hasil penelitian sulit untuk membuktikan adanya money politics, karena yang tahu hanya si pemberi dan si penerima, bagaimana cara komunikasi antara mereka pun tidak diketahui secara persis. Hanya orang-orang tertentu yang sudah ahli dalam bidang ini. Yang bisa menentukan sasaran yang tepat untuk dapat melakukan money politics. Perlu adanya kampanye gerakan masyarakat untuk menolak politik uang, karena politik uang adalah sesuatu yang busuk, ini bermaksud dalam rangka pembentukan pemerintahan yang bersih dan berwibawa, pencerahan secara terstruktur dilakukan melalui program pemerintah, penyelenggara (KPU, Panwaslu) dalam memberikan pencerahan nilai edukatif untuk masalah pendidikan politik yang baik. Tidak hanya melihat yang salah lalu melaporkan. Tetapi di setiap tubuh institusi harus membawa nilai-nilai yang memberikan pencerahan politik kepada masyarakat.

Dalam melaksanakan atau melakukan aksi sesuatu, tentu dibutuhkan yang namanya strategi. Strategi yang dilakukan dalam praktik politik uang dalam pemilu 2019 diantaranya adalah:

\section{Serangan Fajar}

Serangan fajar merupakan kegiatan yang dilalkukan dengan bentuk memberi uang dalam rangka untuk membeli suara yang dilakukan oleh satu atau beberapa orang untuk memenang salah satu calon yang akan menduduki suatu posisi sebagai pimpinan politik pada pagi hari sebelum pelaksanaan pemilhan umum dilakukan (Dedi Irawan, 2015: 3). Serangan fajar biasanya tertuju pada rakyat bawah dan kerap terjadi pada pelaksanaan pemilu. Bentuk praktik politik uang yang dilakukan adalah dengan cara memberi uang menjelang hari pemungutan suara dengan tujuan rakyat memilih caleg tertentu.

\section{Mobilisasi Masa}

$\begin{array}{rrr}\text { Mobilisasi massa } & \begin{array}{r}\text { merupakan } \\ \text { bentuk }\end{array} & \text { pengumpulan }\end{array}$ orang/masyarakat dalam sebuah forum/kegiatan. Caleg dengan cara membeli dan pemilih yang mejual suaranya. Pembelian suara dapat diartikan juga sebagai manfaat lainnya kepada pemilih dengan tujuan utuk mendukung suatu caleg tertentu (Dedi Irawan, 2015: 3). Sehingga dalam pemilihan umum itu kandidat tersebut dapan memperoleh suara masyarakat banyak dengan memobilisasi masyarakat.

Berdasarkan hasil temuan penelitian diperoleh data bahwa bentuk politik uang dalam pelaksanaan Pemilu 2019 di Desa Pulosari dilakukan oleh para caleg dan tim sukses dengan mendatangi pertemuan-pertemuan warga tingkat RT. Tokoh masyarakat dan perangkat Desa Pulosari pada dasarnya sudah menghimbau kepada para warga masyarakat untuk tidak menerima politik uang, namun himbauan tersebut sulit dilaksanakan oleh masyarakat dengan berbagai alasan, diantaranya karena keterbatasan ekonomi dan rendahnya pemahaman masyarakat mengenai pelaksanaan pemilu bagi pembangunan.

Tokoh masyarakat dan perangkat desa Pulosari dalam upaya menanggulangi politik uang dalam Pemilu 2019 hanya sebatas menghimbau dan tidak bisa mengintervensi warga untuk tidak menerima politik uang. Politik uang yang terjadi dalam pemilu 2019 pada dasarnya bukan rahasia, namun tokoh masyarakat yang mengetahui adanya politik uang tidak berani melaporkan kepada pihak yang berwenang yaitu Bawaslu tingkat Kecamatan Kebakkramat, dengan alasan tidak ingin terlibat dalam urusan pemilu serta merasa sungkan dengan caleg dan tim sukses yang melakukan politik uang karena sudah kenal dan merupakan kerabat dari warga masyarakat Desa Pulosari. 
Berdasarkan hasil informasi yang diperoleh dari informan penelitian diketahui bahwa caleg yang melakukan politik uang di Desa Pulosari yaitu caleg A dari Partai X, yang dilakukan dengan membagi-bagikan uang kepada masyarakat dengan kisaran $30 \mathrm{rb}-50 \mathrm{rb}$. yang dilakukan pada saat pertemuan warga tingkat RT.

Pelaksanaan pemilu 2019 diharapkan menjadi pesta demokrasi bagi rakyat Indoensia dalam menentukan pemimpin. diperlukan sistem pemilu yang bersih dari praktik-praktik politik uang. Menurut Anna Valiana dan Anita Trisiana (2018: 25) yang menyatakan bahwa pemilihan umum (Pemilu) adalah sebuah demokrasi yang menjadi ajang bagi kedaulatan rakyat. Dalam negara demokratis, pemilu yang merupakan cerminan suara rakyat menjadi penentu bagi keberlangsungan sebuah negara untuk menentukan nasib dan tujuan sebuah bangsa dan negara.

\section{KESIMPULAN DAN SARAN}

Berdasarkan hasil penelitian diperoleh kesimpulan bahwa: 1) Peran masyarakat dalam menanggulangi politik uang dalam pelaksanaan pemiliham umum 2019 di Desa Pulosari Kecamatan Kebakkramat Kabupaten Karanganyar masih rendah, masyarakat Desa Pulosari cenderung membiarkan dan bersikap terbuka terhadap praktik politik uang yang terjadi di desanya dan tidak melaporkan praktik politik uang tersebut kepada pihak pengawas pemilu. 2) Faktor-faktor yang melatarbelakangi masyarakat Pulosari dalam melakukan Money politics dalam pemilu yaitu karena masalah ekonomi, kebiasaan ketika pemilu, pendidikan politik yang rendah, sehingga masyarakat cenderung terbuka dan menerima kegiatan money politics yang dilakukan oleh calon kandidat dan menerima segala macam bentuk pemberian. Pemberian uang yang membuat masyarakat merasa wajib untuk mengikuti proses pemilu karena adanya bentuk kesepakatan tidak tertulis dengan unsur-unsur paksaan dari para pelaku money politics. 3) Upaya yang dapat dilakukan menanggulangi politik uang dalam pelaksanaan pemiliham umum 2019 di Desa Pulosari Kecamatan Kebakkramat Kabupaten Karanganyar yaitu dilakukan dengan memberikan pendidikan politik kepada masyarakat serta melaporkan kejadian politik uang kepada pengawas pemilu yang disertai dengan bukti-bukti yang cukup.

\section{Saran}

Berdasarkan kesimpulan hasil penelitian yang telah dikemukakan, saran yang dapat disampaikan dalam penelitian ini adalah:

1. Perlu dilakukan pendidikan politik secara terus menerus terutama sebelum pemilu di dalam masyarakat tentang akibat atau dampak negatif dari Money Politics, kegiatan ini dimulai dengan sosialisasi yang dilakukan para tim sukses masing-masing kandidat atau bisa juga melalui kader-kader partai politik dan diawasi dengan badan pemilu setempat mengenai bahaya Money Politics. Hal ini dilakukan untuk membentuk pandangan masyarakat bahwa Money Politics memiliki dampak-dampak yang merugikan dalam jangka panjang apabila salah dalam menentukan pilihan calon pemimpin. Perlu juga menekankan kepada pemilih agar lebih mengutamakan memilih berdasarkan rekam jejak atau track record calon kepala daerah. Selain itu diharapkan dapat mengontrol tindakan timses kandidat maupun kader-kader partai politik agar bersama-sama berjuang secara fair.

2. Pemikiran calon kandidat dimana money politic sebanarnya tidak terlalu menjamin kepastian akan jumlah suara 
yang yang didapat sesuai dengan dana yang telah dikelurkan dan perlunya Ada aturan yang jelas dan tegas untuk diberlakukan kepada masyarakat melalui pendekatan secara personal apabila masih ada oknum simpatisan atau tim sukses yang melakukan politik uang untuk menolak pemberian atau menerima pemberiannya tetapi jangan memilih pasangan kandidat yang mereka usung, karena jelas mereka sudah melakukan tindakan yang salah yakni tindakan yang termasuk ke kategori korupsi dengan memberikan sogokan. Hal ini diharapkan agar dapat memberikan efek jera kepada baik tim sukses maupun pasangan kandidat yang melakukan praktik politik uang di masyarakat. Diharapkan pada akhirnya dapat membentuk penyadaran kepada simpatisan atau kandidat bahwa melakukan strategi politik uang adalah hal yang sia-sia.

\section{DAFTAR PUSTAKA}

Ahsan Jamet Hamidi, 2008, Pemilu Tidak Bebas Politik Uang, Jakarta: Transparancy International Indonesia.
Anna Valiana dan Anita Trisiana, 2018, Analisis Strategi Komunikasi Politik Terhadap Partisipasi Politik Pemenangan Rudi Dan Purnomo Dalam Pilkada 2015 Kota Surakarta, Jurnal Global Citizen, Volume 2 Nomor 2, Desember 2018.

Antara, panwaslu-terima-5-pengaduanmoney-politics, Diakses Tanggal 01 Januari 2019.

Dedi Irawan, 2005, Studi Tentang Politik Uang (Money Politic) Dalam Pemilu Legislatif Tahun 2014: Studi Kasus Di Kelurahan Sempaja Selatan, Jurnal Ilmu Pemerintahan, Maret, 2015

Indra Ismawan, 2009, Money Politics: Pengaruh Uang Dalam Pemilu, Cet.Ke-1, Yogyakarta: Media Presindo.

Miriam Budiardjo, 2010, Dasar-Dasar Ilmu Politik, Jakarta: PT. Gramedia Pustaka.

Moh. Mahfud MD, 1999, Hukum dan Pilar-Pilar Demokrasi, Yogyakarta: Penerbit Gama Media. 